\title{
Penyuluhan Risiko Keracunan Pestisida dan Pemeriksaan Kesehatan pada Ibu Hamil
}

\author{
Prayudhy Yushananta ${ }^{1 *}$, Iwan Sariyanto ${ }^{2}$, Yetti Anggraini ${ }^{3}$, Mei Ahyanti ${ }^{4}$, \\ Enro Sujito ${ }^{5}$, Bambang Murwanto ${ }^{6}$ \\ 1,2,3,4,5 Politeknik Kesehatan Tanjungkarang, Jl. Soekarno - Hatta No.1, Hajimena, Kec. Natar, Kabupaten \\ Lampung Selatan, Lampung 35145 \\ Email: prayudhyyushananta@gmail.com ${ }^{1}$
}

\begin{abstract}
ABSTRAK
Keracunan pestisida merupakan masalah kesehatan yang kritis pada pertanian hortikultura, akibat dari penggunaan dosis berlebihan, cara penanganan yang salah, dan tidak menggunakan APD secara lengkap. Salah satu efek kronis keracunan pestisida adalah anemia. Pada kehamilan, anemia menyebabkan gangguan pertumbuhan intrauterin sehingga bayi lahir BBLR dan pendek (stunted). Pengabdian masyarakat bertujuan untuk meningkatkan pengetahuan ibu hamil tentang risiko paparan pestisida, serta memeriksa kadar kolinesterase dan $\mathrm{Hb}$. Penyuluhan dengan penilaian diberikan kepada 50 orang ibu hamil, dan dilanjutkan dengan pengambilan sampel darah untuk pemeriksaan kesehatan. Hasil pengabdian menunjukkan peningkatan pengetahuan yang signifikans pada sebagian besar peserta ( $\mathrm{p}$-value $<0,01)$. Pada pemeriksaan kesehatan, didapatkan sebanyak 30\% ibu hamil mengalami keracunan pestisida dan $16 \%$ anemia, menunjukkan paparan pestisida yang tinggi dan perlindungan diri yang rendah. Pada akhir kegiatan, seluruh peserta diberikan buku saku tentang pengelolaan pestisida yang aman, sebagai media pembelajaran dan perluasan informasi. Sebanyak 500 eksemplar juga diserahkan kepada Dinas Kesehatan Lampung Barat, untuk dibagikan kepada ibu hamil di kecamatan lainnya. Penyuluhan yang disertai dengan penyampaian bukti gangguan kesehatan telah mampu memicu perubahan perilaku sasaran, terlihat dari peningkatan penggunaan APD selama bekerja, dan pemeriksaan kehamilan. Pengabdian diharapkan dapat dilakukan secara berkelanjutan dan melibatkan banyak mitra.
\end{abstract}

Kata kunci: Anemia, APD, Hortikultura, Keracunan, Penyuluhan, Pestisida

\begin{abstract}
Pesticide poisoning is a critical health problem in horticultural agriculture due to excessive doses, wrong handling methods, and incompletely using PPE. One of the chronic effects of pesticide poisoning is anemia. In pregnancy, anemia causes intrauterine growth disorders so that the baby is born LBW dan stunted. This community service aims to increase pregnant women's knowledge about pesticides' risks and check cholinesterase dan $\mathrm{Hb}$ levels. Counseling with assessments was given to 50 pregnant women, followed by taking blood samples for health checks. The services results showed a significant increase in knowledge in most participants (p-value <0.01). On the medical check, it was found that $30 \%$ of pregnant women experienced pesticide poisoning dan 16\% anemia, indicating high pesticide exposure dan low selfprotection. At the end of the activity, all participants were given pocketbooks on safe pesticide management as a medium for learning and expanding information. A total of 500 copies were also handed over to the West Lampung Health Office to be distributed to pregnant women in other districts. Counseling accompanied by the delivery of evidence of health problems has triggered changes in the target behavior, as seen in the increased use of PPE during work dan antenatal care. The service is expected to be carried out sustainably and involves many partners.
\end{abstract}

Keywords: Anemia, PPE, Horticulture, Poisoning, Counseling, Pesticides 


\section{PENDAHULUAN}

Keracunan pestisida masih menjadi persoalan kesehatan yang penting pada pekerja pertanian. Diperkirakan lima juta kasus dilaporkan setiap tahunnya, dengan 220.000 kematian (Kartini dkk., 2019). Pestisida adalah bahan kimia yang digunakan untuk membasmi hama, termasuk serangga, gulma, jamur, dan kelompok rodent. Berdasarkan kimiawinya, dikelompokkan menjadi senyawa chlorin, phosphate, carbamat, dan biopesticide (Shaban dkk., 2016).

Pestisida yang masuk ke dalam tubuh akan menghambat kerja enzim cholinesterase, sehingga terjadi penumpukan asetylkolin yang bertugas sebagai penghubung impuls syaraf ke sel otot. Akibatnya, terjadi diskoordinasi kerja otot yang ditdanai dengan tremor, kejang, dan sakit kepala. Keracunan dalam jangka waktu lama (kronis), dapat menyebabkan anoreksia, anemia, dan neuropati (Agustina dan Norfai, 2018; Britt dan Budinky A, 2000; Sihana dkk., 2019). Pada masa kehamilan, anemia merupakan faktor risiko pendarahan pada persalinan, dan gangguan pertumbuhan intrauterin sehingga bayi lahir dengan barat badan rendah $(L B W)$, pendek (stunted), kekebalan tubuh yang rendah, hingga kematian perinatal (Destarina, 2018; Eskenazi dkk., 2004; Fenster dkk., 2006; Harley dkk., 2016; Petit dkk., 2012, 2010; Rustia dkk., 2010; Soeprono, 1988).

Pemeriksaan keracunan pestisida dilakukan dengan mengukur kadar cholinesterase dalam darah (metode tintometry), dan dinyatakan mengalami keracunan jika jumlahnya kurang dari $3.990 \mu / \mathrm{L}$. Faktor-faktor yang berkaitan erat dengan keracunan pestisida antara lain pengetahuan, dosis berlebihan, lama paparan, cara penyemprotan, dan penggunaan pelindung diri (Agustina dan Norfai, 2018; Del Prado-Lu, 2007; Yushananta dkk., 2020b, 2020a). Selain saat penyemprotan, Paparan pestisida terjadi mulai saat mencampur, menyemprot, mencuci peralatan, merawat tanaman, dan pemanenan (Yushananta dkk., 2020b).

Pertanian hortikultura merupakan bidang pertanian yang paling banyak menggunakan pestisida. Dosis tinggi digunakan secara terus-menerus, sejak mulai pembibitan hingga siap panen. Penyemprotan tanaman dilakukan hingga tiga kali dalam seminggu, dan non indikatif (Prasetyaningsih dkk., 2017). Selain manusia, penggunaan pestisida yang tidak tepat juga akan berdampak pada serangga non-hama, terakumulasi pada hasil panen, dan pencemaran lingkungan (Istianah. dan Yuniastuti, 2017; Shaban dkk., 2016; Suparti dkk., 2016). 
Kabupaten Lampung Barat memiliki daerah pertanian hortikultura terluas di Provinsi Lampung, lebih kurang 1.254 Ha (BPS, 2019). Hasil pengukuran di empat kecamatan sentra hortikultura mendapatkan, sebanyak $24,6 \%$ petani mengalami keracunan, $54,1 \%$ tidak menggunakan pelindung secara lengkap, dan kedua variabel menunjukkan hubungan yang sangat erat (Yushananta dkk., 2020b). Demikian pula pada kelompok wanita usia subur, sebanyak 68,39\% bekerja dengan pelindung diri tidak lengkap, 8,39\% mengalami keracunan dan 22,58\% anemia (Yushananta dkk., 2020a). Hasil ini menunjukkan tingginya risiko keracunan pada petani hortikultura, terutama pada WUS yang akan berdampak pada kehamilan dan janin.

Pengabdian masyarakat bertujuan meningkatkan pengetahuan tentang risiko keracunan, serta melakukan pemeriksaan kadar cholinesterase dan $\mathrm{Hb}$. Sasaran pengabdian adalah ibu hamil yang bekerja pada pertanian hortikultura. Penentuan sasaran mengingat dampak lanjutan keracunan pada kehamilan dan perkembangan janin.

\section{METODE}

Kegiatan pengabdian dilaksanakan pada bulan Agustus 2020, di wilayah kerja Puskesmas Liwa, Kecamatan Balik Bukit, Kabupaten Lampung Barat. Kecamatan Balik Bukit adalah ibukota kabupaten, serta salah satu sentra pertanian hortikultura. Luas wilayah sekitar 175,63 $\mathrm{Km}^{2}$ dan jumlah penduduk sebanyak 40.925 jiwa, merupakan kecamatan terpadat di Kabupaten Lampung Barat (BPS, 2020). Tim pengabdi adalah dosen Politeknik Kesehatan Tanjungkarang, serta mahasiswa yang berdomisili di Kota Liwa. Mitra pengabdian adalah Dinas Kesehatan Lampung Barat dan Puskesmas Liwa.

Pengabdian masyarakat dilaksanakan dalam tiga tahapan kegiatan, yaitu persamaan persepsi, penyuluhan, dan pemeriksaan kesehatan. Persamaan persepsi dilakukan bersama Dinas Kesehatan Lampung Barat dan Puskesmas Liwa, untuk menyusun rencana kerja, serta pembagian peran pada setiap tahapan kegiatan. Penyuluhan dilakukan di kelas ibu hamil, dengan materi tentang risiko pestisida dan pengelolaan pestisida yang aman. Sebelum dan sesudah penyuluhan, seluruh peserta diberikan 20 pertanyaan secara tertulis tentang risiko pestisida dan pengelolaan pestisida. Uji T (pada Confident Level 95\%) dengan SPSS 24.0 diterapkan untuk mengetahui pengaruh penyuluhan terhadap peningkatan pengetahuan peserta.

Pemeriksaan kesehatan dilakukan setelah tahapan penyuluhan dan penilaian hasil penyuluhan. Pemeriksaan kesehatan untuk mengetahui tingkat keracunan (kadar cholinesterase) dan status anemia (kadar $H b$ ) dalam darah seluruh peserta. Sebelum 
pengambilan sampel darah, seluruh peserta diberi penjelasan tentang tata cara pengambilan sampel, serta diberikan kebebasan untuk menolak pengambilan sampel. Pemeriksaan $\mathrm{Hb}$ dilakukan insitu menggunakan metode POCT. Sedangkan untuk cholinesterase, serum dipisahkan dengan centrifuge, selanjutnya dibawa ke laboratorium pada suhu $4^{\circ} \mathrm{C}$, dan dianalisis dengan metode Tintometry.

Pada akhir kegiatan, seluruh peserta diberikan buku saku tentang pengelolaan pestisida yang aman. Buku saku berisi tentang tata cara penanganan pestisida sejak mulai dibeli hingga membuang kemasan, serta pertolongan pertama jika terjadi peristiwa keracunan.

\section{HASIL, PEMBAHASAN DAN DAMPAK}

\section{Penyuluhan}

Penyuluhan dilakukan secara berkelompok di kelas ibu hamil, dan secara perorangan pada beberapa ibu hamil yang berhalangan hadir. Materi penyuluhan adalah penanganan pestisida secara aman sejak dibeli hingga pembuangan kemasan, tata cara penyemprotan, risiko terhadap kesehatan termasuk kehamilan dan janin, alat pelindung diri wajib pakai (APD), serta pertolongan pertama keracunan. Penyampaian materi oleh pengabdi didampingi mitra, yaitu Puskesmas Liwa dan Dinas Kesehatan Lampung Barat. Pelibatan petugas kesehatan penting dalam perubahan perilaku kesehatan masyarakat (Sari dkk., 2019).

Tabel 1. Hasil penilaian pengetahuan

\begin{tabular}{llllll}
\hline Penilaian pengetahuan & $\mathrm{n}$ & Mean & $\mathrm{SD}$ & $\mathrm{T}$ & P-value \\
\hline Sebelum penyuluhan & 50 & 48,56 & 5,71 & 32,40 & 0,0001 \\
Sesudah penyuluhan & 50 & 70,06 & 2,45 & & \\
\hline \hline
\end{tabular}

Dilakukan pengukuran untuk mengetahui perubahan tingkat pengetahuan sebelum dan sesudah penyuluhan. Hasil pengukuran mendapatkan nilai rata-rata pengetahuan sebelum penyuluhan sebesar 48,56 ( $\mathrm{SD}=5,71)$, dan sesudah penyuluhan menjadi 70,06 $(\mathrm{SD}=2,45)$, terjadi peningkatan sebesar 21,50 (Tabel 2). Hasil uji statistik menunjukkan perbedaan nilai pengetahuan yang signifikans antara sebelum dan sesudah penyuluhan $(p$ value $<0,01)$. Hasil ini menyimpulkan bahwa metode, cara penyampaian dan materi yang diberikan dapat diterima peserta dengan baik. Meningkatnya pengetahuan diharapkan memicu terjadinya perubahan perilaku. Menurut Fauziyah dkk, rendahnya pengetahuan petani terhadap risiko paparan pestisida menyebabkan perilaku yang buruk dalam penggunaan APD (Fauziyyah dkk., 2017). 


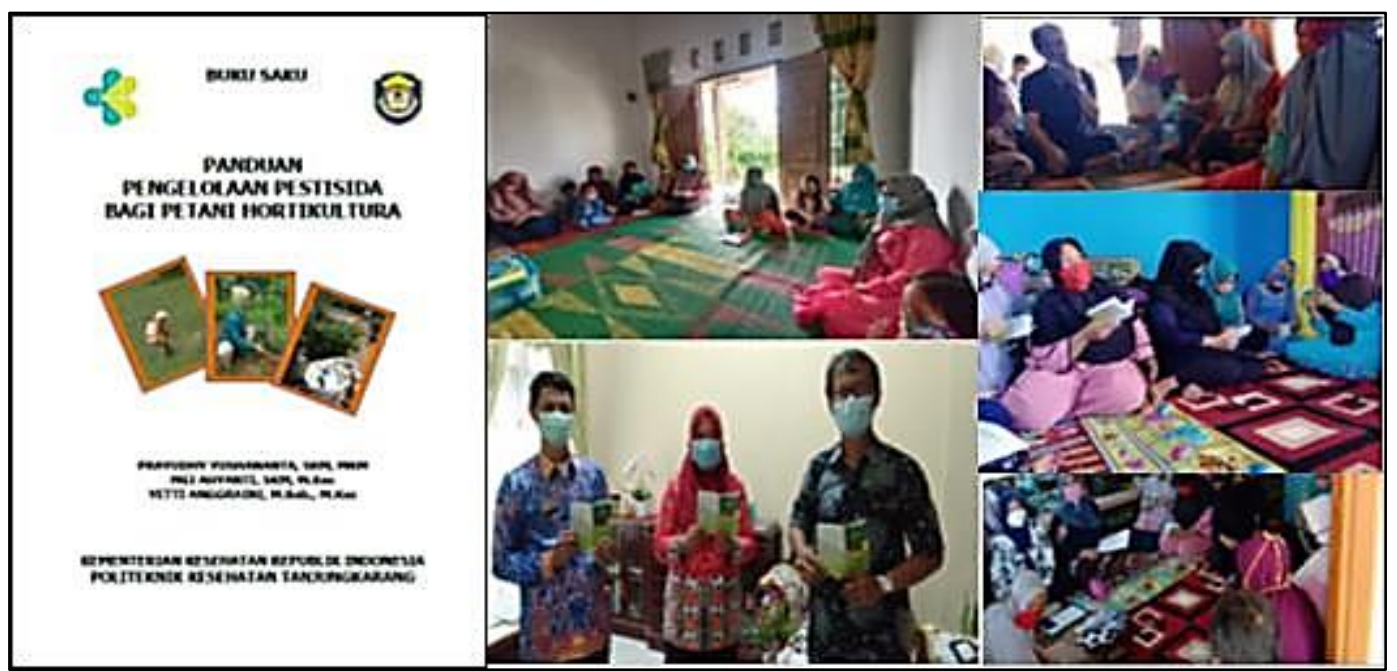

Gambar 1. Kegiatan Penyuluhan dan penyerahan buku saku

Kepada seluruh sasaran pengabdian, dibagikan buku saku tentang pengelolaan pestisida secara aman. Buku saku dikembangkan oleh pengabdi sebagai sebagai media pembelajaran dan penyebaran informasi bagi petani. Diharapkan, buku saku dapat menjadi pedoman dalam pananganan pestisida yang aman sehingga tidak memberikan risiko terhadap kesehatan. Buku saku berisi tentang cara mencampur, mengaplikasikan, menyimpan, mebersihkan peralatan dan pakaian, APD, pembuangan kemasan, serta pertolongan pertama jika terjadi keracunan pestisida. Selain dibagikan kepada seluruh peserta penyuluhan (sasaran pengabdian), sebanyak 500 eksemplar buku saku juga diserahkan kepada Dinas Kesehatan Lampung Barat, untuk dibagikan kepada ibu hamil di kecamatan lainnya (Gambar 1).

\section{Pemeriksaan Kesehatan}

Pemeriksaan kesehatan dilakukan terhadap dua parameter, yaitu kadar $H b$ dan cholinesterase. Hasil pemeriksaan (Tabel 2) memperlihatkan bahwa sebanyak 30\% ibu hamil mengalami keracunan pestisida, dan $16 \%$ mengalami anemia. Hasil ini mengkonfirmasi hasil pelitian di beberapa daerah hortikultura (Agustina dan Norfai, 2018; Arwin dan Suyud, 2016; Fauziyyah dkk., 2017; Prasetyaningsih dkk., 2017; Yushananta dkk., 2020a).

Masuknya pestisida ke dalam tubuh terutama melalui kulit dan pernafasan, terutama pada saat mencampur, meyemprot, kontak dengan tanaman dan peralatan yang mengdanung residu pestisida, serta menghirup uap air yang bercampur residu. Penyemprotan pestisida yang melawan arah angin akan meningkatkan masuknya pestisida ke dalam tubuh (Kementan, 2020; Kurniasih dkk., 2013; Okvitasari dkk., 2016). 
Penyemprotan pada saat suhu udara mulai panas akan meningkatkan penguapan, sehingga jumlah uap air yang bercampur residu juga akan meningkat (Kementan, 2020; Novizan, 2008). APD peralatan yang digunakan selama menangani pestisida dengan tujuan menutup seluruh pintu masuk ke dalam tubuh (portal of entry), yaitu baju lengan panjang, sarung tangan, masker, topi, dan sepatu boot. Keengganan menggunakan APD menunjukkan rendahnya pengetahuan petani tentang risiko paparan pestisida (Arwin dan Suyud, 2016; Fauziyyah dkk., 2017; Yushananta dkk., 2020b, 2020a).

Tabel 2. Hasil Pemeriksaan Kadar Cholinesterase dan Hemoglobin Ibu Hamil

\begin{tabular}{llllll}
\hline Cholinensterase & $\mathrm{n}$ & $\%$ & Kadar $\mathrm{Hb}(\mathrm{g} / \mathrm{dL})$ & $\mathrm{n}$ & $\%$ \\
\hline Keracunan & 15 & 30,0 & Rendah (Anemia) & 8 & 16,0 \\
Normal & 35 & 70,0 & Normal & 42 & 84,0 \\
\hline \hline
\end{tabular}

Pada kasus keracunan jangka panjang, akan terbentuk ikatan sulfur dari pestisida dengan hemoglobin membentuk sulfhemoglobin. Oksidasi berlebihan akibat terhambatnya enzim cholinesterase akan merubah senyawa ferro dalam erytrocit menjadi ferri, dan membentuk methemoglobin. Kedua bahan akan mengganggu fungsi $\mathrm{Hb}$ untuk mengikat dan menghantarkan oksigen, akibatnya terjadi enemia (Britt dan Budinky A, 2000; Del Prado-Lu, 2007; George dkk., 2014; Nutakki dkk., 2017, 2016; Sihana dkk., 2019). Anemia pada kehamilan akan meningkatkan risiko pendarahan dan mengganggu perkembangan intrauterin (Eskenazi dkk., 2004; George dkk., 2014; Petit dkk., 2012, 2010; Whyatt dkk., 2004).

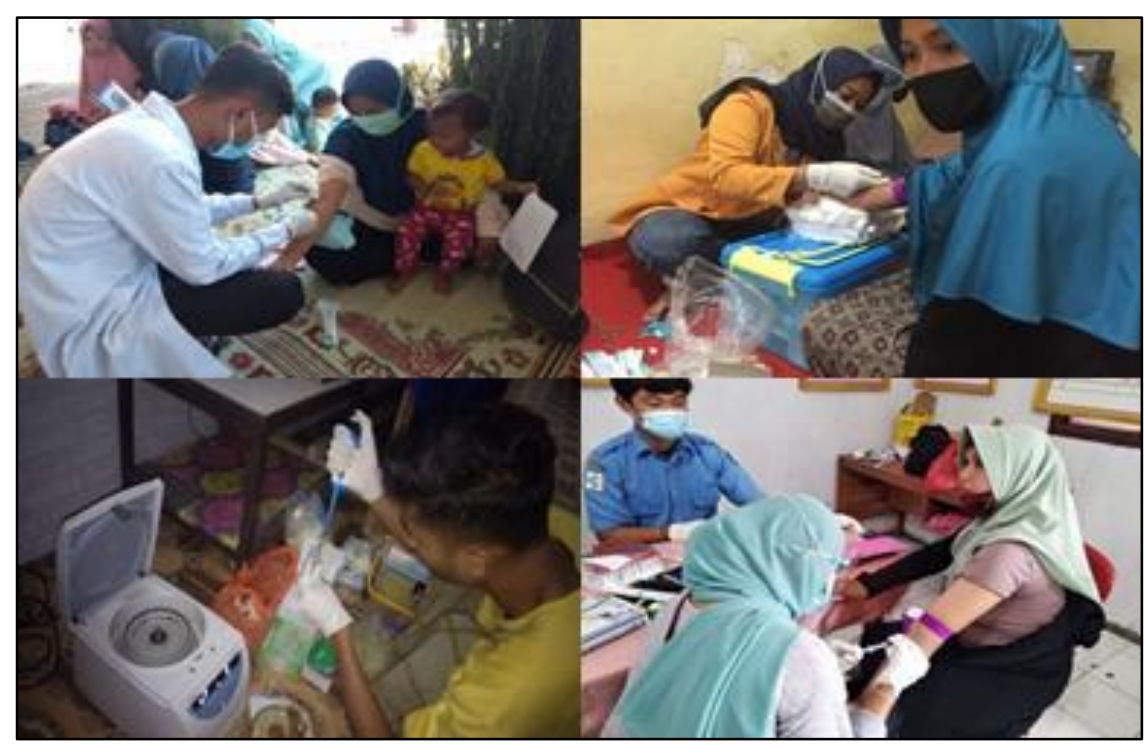

Gambar 2. Pemeriksaan Kadar Hb dan Cholinesterase

Meningkatnya pengetahuan disertai dengan penyampaian bukti keracunan pestisda dan anemia berdasarkan hasil pengukuran, menjadi pemicu terjadinya perubahan sikap dan 
perilaku sasaran dalam melakukan pekerjaan yang berkaitan dengan pestisida. Hasil pengamatan dan wawancara menunjukkan peningkatan penggunaan APD pada saat bekerja, serta adanya perluasan informasi kepada keluarga. Berdasarkan laporan bidan penanggungjawab wilayah, terjadi peningkatan kunjungan pemeriksaan ibu hamil (ANC) dan pemeriksaan anemia. Hasil-hasil ini menunjukkan adanya perubahan perilaku pada sasaran pengabdian, terutama dalam pencegahan keracunan pestisida dan pemeliharaan kesehatan selama kehamilan.

\section{SIMPULAN}

Pengabdian masyarakat untuk meningkatkan pengetahuan tentang risiko keracunan dapat dilaksanakan dengan baik. Sasaran pengabdian sebanyak 50 orang ibu hamil yang bekerja pada pertanian hortikultura. Hasil penyuluhan mampu meningkatkan pengetahuan tentang penanganan pestisida pada mayoritas sasaran (90\%), dan secara statistik menunjukkan perubahan tingkat pengetahuan yang signifikans. Hasil pemeriksaan kesehatan mendapatkan 30\% ibu hamil menderita keracunan dan 16\% anemia, menunjukkan tingginya tingkat paparan pestisida serta rendahnya perlindungan dari paparan pestisida. Sebagai media pembelajaran dan informasi, telah dibagikan buku saku pengelolaan pestisida kepada seluruh sasaran pengdanian, serta menyerahkan 500 eksemplar kepada Dinas Kesehatan Lampung Barat, untuk dibagikan kepada ibu hamil di kecamatan lainnya. Diharapkan kegiatan pengabdian dapat dilakukan secara berkelanjutan, dan melibatkan mitra yang lebih luas. Selain perluasan lingkup sasaran, juga melakukan pengmbangan, salah satunya adalah pelatihan pembuatan pestisida alami (biopesticide).

\section{UCAPAN TERIMA KASIH}

Ucapan terima kasih disampaikan kepada Dinas Kesehatan Kabupaten Lampung Barat, Puskesmas Liwa, seluruh relawan, serta penerima manfaat kegiatan pengabdian masyarakat.

\section{DAFTAR PUSTAKA}

Agustina, N., Norfai, N., 2018. Paparan Pestisida terhadap Kejadian Anemia pada Petani Hortikultura. Majalah Kedokteran Bdanung 50, 215-221.

Arwin, N.M., Suyud, S., 2016. Pajanan pestisida dan kejadian anemia pada petani holtikultura di Kecamatan Cikajang , Kabupaten Garut tahun 2016. Berita Kedokteran Masyarakat 32, 245-250. 
BPS, 2019. Provinsi Lampung Dalam Angka 2019. BPS Provinsi Lampung, Bdanar lampung.

BPS, K.L.B., 2020. Kecamatan Balik Bukit Dalam Anka 2020, 1st ed. BPS, Kabupaten Lampung Barat, Liwa.

Britt, J.K., Budinky A, R., 2000. Principles of toxicology: Environmental dan Industrial Applications, 2nd edition, 2nd ed, John Wiley \& Sons, Inc. John Wiley \& Sons, Inc, Canada.

Del Prado-Lu, J.L., 2007. Pesticide exposure, risk factors dan health problems among cut flower farmers: A cross sectional study. Journal of Occupational Medicine dan Toxicology 2, 1-8.

Destarina, R., 2018. Risk Factors of Anemia Status among Pregnant Woman on Stunted Birth Length in Puskesmas Sentolo 1, Kulon Progo D.I. Yogyakarta. Journal of The Indonesian Nutrition Association 41, 39-48.

Eskenazi, B., Harley, K., Bradman, A., Weltzien, E., Jewell, N.P., Barr, D.B., Furlong, C.E., Holldan, N.T., 2004. Association of in utero organophosphate pesticide exposure dan fetal growth dan length of gestation in an agricultural population. Environmental Health Perspectives 112, 1116-1124.

Fauziyyah, R., Suhartono, Astorina, N., 2017. Studi Praktik Penggunaan Pestisida Dan Kejadian Anemia Pada Petani Buah Di Desa Tunggak Kecamatan Toroh Kabupaten Grobogan. Jurnal Kesehatan Masyarakat (e-Journal) 5, 860-870.

Fenster, L., Eskenazi, B., Danerson, M., Bradman, A., Harley, K., Hernandez, H., Hubbard, A., Barr, D.B., 2006. Association of in utero organochlorine pesticide exposure dan fetal growth dan length of gestation in an agricultural population. Environmental Health Perspectives 114, 597-602.

George, T., Shaikh, A., Thomas, L., Kundavaram, A., 2014. Severe methemoglobinemia due to insecticide poisoning. Indian Journal of Critical Care Medicine 18, 113-114.

Harley, K.G., Engel, S.M., Vedar, M.G., Eskenazi, B., Whyatt, R.M., Lanphear, B.P., Bradman, A., Rauh, V.A., Yolton, K., Hornung, R.W., Wetmur, J.G., Chen, J., Holldan, N.T., Barr, D.B., Perera, F.P., Wolff, M.S., 2016. Prenatal exposure to organophosphorus pesticides dan fetal growth: Pooled results from four longitudinal birth cohort studies. Environmental Health Perspectives 124, 1084-1092.

Istianah., Yuniastuti, A., 2017. Hubungan Masa Kerja, Lama Menyemprot, Jenis Pestisida, Penggunaan APD dan Pengelolaan Pestisida dengan Kejadian Keracunan Pada Petani di Brebes. Public Health Perspective Journal 2, 117-123.

Kartini, A., Subagio, H.W., Hadisaputro, S., Kartasurya, M.I., Suhartono, S., Budiyono, B., 2019. Pesticide exposure dan stunting among children in agricultural areas. International Journal of Occupational dan Environmental Medicine 10, 17-29.

Kementan, B., 2020. Teknik Penyemprotan Pestisida. Balitbang Pertanian, Kemnetan RI.

Kurniasih, S.A., Setiani, O., Nugraheni, S.A., 2013. Faktor-faktor yang Terkait Paparan 
Pestisida dan Hubungannya dengan Kejadian Anemia pada Petani Hortikultura di Desa Gombong Kecamatan Belik Kabupaten Pemalang Jawa Tengah. Jurnal Kesehatan Lingkungan Indonesia 12, 132-137.

Novizan, 2008. Petunjuk Pemakaian Pestisida, 1st ed. AgroMedia Pustaka, Jakarta.

Nutakki, G., Siripurapu, I., Kumar, C., SasiSekhar, T., 2017. Methemoglobinemia Due To Biological Poisoning - Case Report. International Journal of Advanced Research 5, 2079-2082.

Nutakki, G.S., Madhav Makineni, V., Madhukiran, 2016. Methemoglobinemia Due to Pesticide Poisoning: A Case Report. IOSR Journal of Dental dan Medical Sciences $15,12-17$.

Okvitasari, R., Anwar, C., Suparmin, 2016. Hubungan Antara Keracunan Pestisida Dengan Kejadian Anemia Pada Petani Kentang Di Gabungan Kelompok Tani Al Farruq Desa Patak Banteng Kecamatan Kejajar Kabupaten Wonosobo Tahun 2016. Politeknik Kesehatan Kemenkes Semarang 299-310.

Petit, C., Blangiardo, M., Richardson, S., Coquet, F., Chevrier, C., Cordier, S., 2012. Association of environmental insecticide exposure dan fetal growth with a Bayesian model including multiple exposure sources: The PELAGIA mother-child cohort. American Journal of Epidemiology 175, 1182-1190.

Petit, C., Chevrier, C., Durdan, G., Monfort, C., Rouget, F., Garlantezec, R., Cordier, S., 2010. Impact on fetal growth of prenatal exposure to pesticides due to agricultural activities: A prospective cohort study in Brittany, France. Environmental Health: A Global Access Science Source 9, 71.

Prasetyaningsih, Y., Arisdani, D., Retnosetiawati, P.D., 2017. Persentase Kejadian Anemia Pada Petani Terpapar Pestisida Di Kelompok Tani Karang Rejo, Dusun Krinjing Lor, Desa Jatisarono, Kecamatan Naggulan, Kabupaten Kulon Progo. In: THE 5TH URECOL PROCEEDING. pp. 452-457.

Rustia, H.N., Wispriyono, B., Susana, D., Luthfiah, F.N., 2010. Lama Pajanan Organofosfat Terhadap Penurunan Aktivitas Enzim Kolinesterase Dalam Darah Petani Sayuran. Makara Kesehatan 14, 95-101.

Sari, S.M., Ennimay, Tengku, A.R., 2019. Pemanfaatan Tanaman Obat Keluarga (TOGA) Pada Masyarakat. Dinamisia : Jurnal Pengabdian Kepada Masyarakat 3, 1-7.

Shaban, N.S., Abdou, K.A., Hassan, N.E.-H.Y., 2016. Impact of toxic heavy metals dan pesticide residues in herbal products. Beni-Suef University Journal of Basic dan Applied Sciences 5, 102-106.

Sihana, F., Dawson, A.H., Buckley, N.A., 2019. A bedside test for methemoglobinemia , Srilanka. Bulletin of the World Health Organization A 1-5.

Soeprono, R., 1988. Anemia Pada Ibu Hamil. Journal od Medical Science XX, 121-135.

Suparti, S., Anies, Setiani, O., 2016. Beberapa Faktor Risiko Yang Berpengaruh Terhadap Kejadian Keracunan Pestisida Pada Petani. Jurnal Kesehatan Pena Medika 6, 125- 
138.

Whyatt, R.M., Rauh, V., Barr, D.B., Camann, D.E., Danrews, H.F., Garfinkel, R., Hoepner, L.A., Diaz, D., Dietrich, J., Reyes, A., Tang, D., Kinney, P.L., Perera, F.P., 2004. Prenatal insecticide exposures dan birth weight dan length among an urban minority cohort. Environmental Health Perspectives 112, 1125-1132.

Yushananta, P., Ahyanti, M., Anggraini, Y., 2020a. Risk of pesticides on anemia events in horticulture farmers. International Journal of Innovation, Creativity dan Change 13, $30-40$.

Yushananta, P., Melinda, N., Mahendra, A., Ahyanti, M., Anggraini, Y., 2020b. Faktor Risiko Keracunan Pestisida Pada Petani Hortikultura di Kabupaten Lampung Barat. Ruwa Jurai: Jurnal Kesehatan Lingkungan 14, 1. 